\title{
PHA665752 inhibits the HGF-stimulated migration and invasion of cells by blocking PI3K/AKT pathway in uveal melanoma
}

\author{
Z. WANG ${ }^{1,2, *}$, C. HE ${ }^{2}$, L. LIU' ${ }^{1}$, N. MA², X. CHEN ${ }^{2}$, D. ZHENG ${ }^{2}$, GH. QIU $3, *$
}

${ }^{1}$ Department of Nursing, School of Pharmaceutical Engineering and Life Science, Changzhou University, Changzhou 213164, Jiangsu, China; ${ }^{2}$ School of Ophthalmology and Optometry, Eye Hospital, Wenzhou Medical University, Wenzhou 325003, Zhejiang, China; ${ }^{3}$ Fujian Provincial Key Laboratory for the Prevention and Control of Animal Infectious Diseases and Biotechnology, School of Life Sciences, Longyan University, Longyan 364012, Fujian, China

${ }^{*}$ Correspondence: wangzhenlian@cczu.edu.cn, qgh@lyun.edu.cn

Received July 25, 2016 / Accepted November 22, 2016

\begin{abstract}
$\mathrm{HGF} / \mathrm{c}-\mathrm{MET}$ is frequently associated with tumor metastasis in many cancers, including uveal melanoma (UM). PHA665752, a selective c-MET inhibitor, exhibits anticancer activity through inhibiting cell motility in some cancers. In this study, we investigated the effects of PHA665752 on UM cell lines M17 and SP6.5. Our data show that HGF stimulated the motility of UM cells, and induced the activation of both c-MET and PI3K/AKT, but not ERK1/2. Moreover, consistent with the amount of c-MET within the nucleus, PHA665752 significantly inhibited HGF-promoted cell motility and suppressed the phosphorylation of c-MET and PI3K/AKT, but not ERK1/2 induced by HGF. Additionally, the effects of PHA665752 on both the inhibition of HGF-induced cell motility and the suppression of active AKT are similar to those of PI3K inhibitor LY294002. In xenograft models, PHA665752 significantly inhibited tumor growth in nude mice and similarly suppressed the phosphorylation of c-MET and PI3K/AKT. Our current findings, combined with previous results, demonstrate that PHA665752 inhibits HGF-induced motility via the inhibition of PI3K/AKT. This study suggests that targeting HGF/c-MET could be a promising therapeutic strategy for UM by preventing cell motility.
\end{abstract}

Key words: Uveal melanoma, PHA665752, HGF, cell migration, cell invasion

Uveal melanoma (UM) is the most common primary malignance in adults [1] and originates from uveal melanocytes, including those of the choroid, ciliarybody, and iris [2]. Despite the existence of a number of effective therapeutic options to eradicate primary UMs and to prevent their local recurrence [3], there are currently no systematic curative therapies for metastatic UMs $[4,5]$. Moreover, patients with metastatic UMs rarely survive more than a year from the time of diagnosis because the metastasis usually occurs in the liver and thus are highly fatal [6]. On the other hand, approximately half of patients diagnosed with primary posterior UMs will develop metastasis [4]. Therefore, it is urgent and crucial to develop novel therapy strategies for improving survival of UM patients by preventing metastasis.

Given the highest propensity to develop metastasis of UM cells in the liver of patients, great efforts have been made to study whether there is any particular symbiosis, such as the homing ability of the metastatic UM cells in hepatic microenvi- ronment that may carry potential for therapeutic intervention $[6,7]$. One of the major focuses of these efforts has been to investigate the signal transduction of the secreted hepatocyte growth factor (HGF), which is produced in liver, and its corresponding tyrosine kinase receptor c-MET [8].

$\mathrm{HGF} / \mathrm{c}-\mathrm{MET}$, which is tightly regulated by various mechanisms under normal conditions, controls cellular signaling pathway cascades, such as PI3K/AKT and MAPK/ERK1/2 in cell growth, proliferation, survival and motility $[9,10]$. Particularly, PI3K/AKT and MAPK/ERK1/2 signaling pathways are important in mediating HGF-induced invasion and metastasis of tumor cells [11-13]. Aberrant HGF/c-MET activation is widely observed in a variety of solid and hematologic malignancies by multiple mechanisms, including promoting tumor cell migration and metastasis $[10,14]$, which in turn drives rapid growth in drug development programs [15]. Therefore, $\mathrm{HGF} / \mathrm{c}-\mathrm{MET}$ inhibition has emerged as attractive targets for anticancer therapies with various strategies [9]. Numerous dif- 
ferent biologicals and small molecular compounds have been discovered with distinct binding modes, selectivity, and safety profiles and are under active development in clinical trials [9, 16]. Notably, two drugs from these compounds, namely Crizotinib and Cabozantinib have been approved by the U.S. Food and Drug Administration for treatment of some cancers [13].

In remarked contrast, the progress on the role of $\mathrm{HGF} / \mathrm{c}$ MET in UM lags behind that in other cancers although many studies have been reported. It has been demonstrated that c-MET plays an important role in the death, growth, migration and metastasis in UM [17-19], and may thus represent a potential target for therapeutic interventions by blocking motility $[6,20,21]$. Moreover, UM cells become highly mobile and invasive when HGF is used as a chemoattractant, suggesting that metastatic UM cells with higher c-MET have greater metastatic potential $[22,23]$. These observations indicate the therapeutic potential of targeting HGF/c-MET pathway to prevent the invasiveness of tumor cells by inhibiting c-MET. In accordance with it, selective targeting of c-MET by Crizotinib has been reported to inhibit metastasis of UM in mouse xenograft models [24]. However, Crizotinib has very marginal effects on inhibition of tumor growth from both primary and metastatic cell lines in UM xenografts [25], and is unable to kill microscopic metastases of retro-orbital injected UM cells that develop rapidly in both the liver and lung[24]. Thus, c-MET inhibition of Crizotinib in UM seems insufficient to prevent tumor growth in vivo [24]. Another c-MET inhibitor MK8033, which can inhibit cell proliferation in GNAQ mutant uveal melanoma cells when combined with MEK inhibitor, has no significant effect on cell proliferation in GNAQ wild-type cells [26]. Therefore, it may be required to develop alternative c-MET inhibitors in UM.

In this regard, PHA665752, another inhibitor of c-MET, could be a good candidate. It is a c-MET selective inhibitor with small molecular weight and displays a minimum of 50 fold selectivity for c-MET relative to several other tyrosine kinases, including receptor tyrosine kinase (e.g. EGFR), tyrosine kinase, serine-threonine kinase, calcium/calmodulindependent protein kinases, and kinases in the families of PKA, PKB, PKC, CDK, MAPK, GSK3 and CLK [27]. It has also been shown that PHA665752 blocks HGF-stimulated activities in cultured cells, selectively inhibits the migration of cancer cells [21] and tumorigenicity in well-characterized c-MET-driven xenograft models of gastric carcinoma $[27,28]$ and lung cancer [29]. In UM, our previous data have clearly demonstrated that the activation of c-MET is required for the enhancement of cell migration induced by HGF in M17 and SP6.5 cells [30]. Therefore, to study the possibility of PHA665752 in therapeutic application to UM, we evaluated the inhibitory effects of PHA665752 on HGF-promoted migration and invasion of UM cells M17 and SP6.5 and investigated the underlying molecular mechanisms. Our in vitro and in vivo results indicate that PHA665752 inhibits the HGF-stimulated migration and invasion of M17 and SP6.5 cells via HGF/c-MET-dependent PI3K/AKT signaling pathway.

\section{Materials and methods}

Reagents. PHA665752 (Sigma, St.Louis, MO) was dissolved in DMSO. LY294002 (in DMSO; Promega) were used at the concentration as described previously [30]. Antibodies against c-MET, phosphospecific (p) c-MET (Tyr 1234/1235), AKT, pAKT (Ser473), ERK1/2 and p-ERK1/2 (Thr202/Tyr204) were purchased from Cell Signaling Technology (Beverly, MA). Recombinant human HGF was from R\&D Systems (Minneapolis, MN). Growth factor-reduced Matrigel was purchased from BD Biosciences (Bedford, MA).

Cell culture. The human UM cell lines M17 and SP6.5 [30] were grown in Dulbecco modified Eagle medium (DMEM) supplemented with $10 \%$ fetal bovine serum (FBS) and incubated at $37^{\circ} \mathrm{C}$ in a humidified incubator containing $5 \% \mathrm{CO}_{2}$.

Protein extraction and Western blotting. M17 and SP6.5 cells $\left(1 \times 10^{5}\right)$ were seeded and grown in 12 -well plates for $48 \mathrm{~h}$, and then starved overnight without FBS. After starvation, cells were pretreated with either PHA665752 or DMSO control for $4 \mathrm{~h}$, followed by the addition of $40 \mathrm{ng} / \mathrm{mL}$ of recombinant human HGF for $30 \mathrm{~min}$, washed with cold phosphate-buffered saline (PBS) and subsequently subjected to the protein extraction with lysis buffer $\left(50 \mathrm{mM} / \mathrm{L}\right.$ Tris ${ }^{\circ} \mathrm{Cl}, 1 \mathrm{mM} / \mathrm{L}$ EDTA, $20 \mathrm{~g} / \mathrm{L}$ sodium dodecyl sulfate (SDS), $5 \mathrm{mM} / \mathrm{L}$ dithiothreitol, $10 \mathrm{mM} / \mathrm{L}$ phenylmethylsulfonyl fluoride). Protein lysates $(50 \mu \mathrm{g})$ were separated by $10 \%$ SDS-polyacrylamide gel electrophoresis (PAGE), and then electrotransferred onto nitrocellulose membranes. The membranes were blocked with buffer containing $5 \%$ fat-free milk and $0.05 \%$ Tween 20 in PBS for 2 hours and incubated overnight with primary antibody at $4{ }^{\circ} \mathrm{C}$. After a second wash of PBS with $0.05 \%$ Tween 20 , the membranes were incubated with peroxidase conjugated secondary antibodies (Santa Cruz Biotechnology) and developed with electrogenerated chemiluminescence (ECL) detection kit (Pierce, Rockford, IL).

MTS cell proliferation assay. The Promega CellTiter 96 AQueous One Solution Cell Proliferation Assay was used, as per the manufacturer's instructions (Promega, Madison, WI). Briefly, cells were seeded in triplicates into 96-well plates (1000 cells/well) and allowed to adhere for 24 hours in serum supplemented ( $10 \%$ fetal calf serum) media. Thereafter, the cells were treated for 24 to 96 hours as indicated in serum-reduced (2\% fetal calf serum) media [31]. HGF (40 ng/mL), PHA665752 or DMSO (vehicle control) was added into the media at the time of cell plating. Absorbance at $490 \mathrm{~nm}$ was measured 2 hours after the addition of $20 \mu \mathrm{l}$ of MTS reagent/well.

Wound closure assay. For wounding assay, cells were grown to $\sim 85 \%$ confluence and serum-starved for $24 \mathrm{~h}$, and a gap was introduced by scraping cells with a P200 pipette tip. Cells are treated as indicated to stimulate to migrate across the gap and photographed using a phase-contrast microscope for the assessment of migration inhibition at the time points of 0,24 , 48 , and $72 \mathrm{~h}$ after wounding.

Assays for migration and invasion. Cell migration was determined in Boyden chambers using uncoated filters (BD 
Biocoat control inserts, BD Biocoat, San Jose, CA). Cell invasion was examined by Polycarbonate membranes $(8.0 \mathrm{~mm}$ pore size) coated with diluted growth factor-reduced Matrigel in the upper compartment of Transwell culture chambers. Briefly, cells were serum-starved for $24 \mathrm{~h}$, resuspended in serum-free medium containing PHA665752 $(1 \mu \mathrm{M}), \mathrm{LY} 294002(20 \mu \mathrm{M})$ or DMSO (vehicle control) and seeded at 50,000 cells/well into cell invasion assay inserts. The medium containing HGF $(40 \mathrm{ng} / \mathrm{mL})$ served as a chemoattractant in the lower chamber. After incubation for $24 \mathrm{~h}$, the membranes were fixed with methanol and stained with haematoxylin and eosin (H\&E). Cells located on the upper surface of the filter were completely removed by wiping the filter with a moist cotton swab, and cells that had migrated through the membrane to the lower surface were counted using a light microscope. Each assay was repeated at least three times.

Immunofluorescence. Location of c-MET and p-c-MET in M17 and SP6.5 cells was detected by immunofluorescence. M17 and SP6.5 cells were cultured on coated glass coverslips for $48 \mathrm{~h}$ and pre-starved overnight in serum-free media. After starvation, cells were pretreated with either DMSO control or PHA665752 for $4 \mathrm{~h}$, followed by the addition of $40 \mathrm{ng} / \mathrm{mL}$ of HGF for $30 \mathrm{~min}$. Coverslips were then rinsed briefly in Tris-buffered saline (TBS), and cells were fixed in $4 \%$ paraformaldehyde solution for $10 \mathrm{~min}$ at room temperature and permeabilized with $0.1 \%$ Triton X-100 in TBS for $3 \mathrm{~min}$. After cells were blocked with TBS containing 5\% bovine serum albumin (BSA) for $1 \mathrm{~h}$, primary antibody against c-MET and p-c-MET was incubated in the blocking solution for $1 \mathrm{~h}$. Cy3-conjugated secondary antibody was incubated for an additional hour in the blocking solution. After three washes with TBS, DNA was counterstained with DAPI-containing mounting solution (Vector Laboratories Inc., Burlingame, CA, USA). The coverslips were visualized and images were captured using a spinning disc confocal microscope (DSU; Olympus, Tokyo, Japan).

In vivo tumor growth assay. Animal treatments were conducted in accordance with the Institute for Laboratory Animal Research Guide for the Care and Use of Laboratory Animals and with SUGEN Animal Care and Use Committee guidelines addressing the proper and humane use of animals. Briefly, the viability of UM cells was examined by trypan blue exclusion. UM cells with $90 \%$ or greater viability were suspended in balanced salt solution with the cell density at $5 \times 10^{6}$ cells $/ 100 \mu \mathrm{L}$. $5 \times 10^{6}$ cells were inoculated into 5 -week-old healthy nude mice subcutaneously. Caliper measurements of tumor volume (length $\times$ width $\times$ height) were conducted every 7 days. Daily treatment with PHA665752 (25 mg/kg i.v.) was initiated when tumors reached $80 \sim 100 \mathrm{~mm}^{3}$ in size, with balanced salt solution as negative control. After drug treatment for 21 days, mice were euthanized and tumor size was measured with calipers.

Immmunohistochemistry. Fresh UM tumors from nude mouse and their paired normal tissues were fixed in 30\% sucrose solution and embedded in frozen blocks. Eight-micrometer-thick consecutive sections were cut and mounted on glass slides. After antigen retrieval, sections were treated with $0.1 \%(\mathrm{v} / \mathrm{v}) \mathrm{H}_{2} \mathrm{O}_{2}$ for $10 \mathrm{~min}$, blocked with serum, and incubated for overnight at $4^{\circ} \mathrm{C}$ with the following antibodies against their respective protein with dilution in brackets: AKT (1:300), p-AKT (1:100), c-MET (1:300) and p-c-MET (1:200). The secondary antibodies were biotinylated goat anti-rabbit IgG. These sections were developed using a peroxidase substrate kit $(\mathrm{DAB})$ and counterstained with Meyer's haematoxylin. Negative-control sections were subjected to the same staining procedure without the primary antibody.

Statistical analysis. All statistical analyses were performed with Statistical Product and Service Solutions (SPSS, v19.0) software. The data presented are mean \pm SD (standard deviation) of triplicates with at least three independent experiments. The paired student's t-test was used for comparison when appropriate. $P<0.05$ is considered statistically significant.

\section{Results}

HGF does not promote and PHA665752 inhibits cell proliferation in UM. HGF has been shown to stimulate cell proliferation in the cell lines of some cancers, such as not only in lung [32], brain [33] and colon [34], and but also in melanoma [35]. To study the effects of HGF on UM cell lines, we first examined cell proliferation after HGF treatment. As shown in Figure 1A, very minimal effects were observed on cell proliferation after treatment of UM cells with $40 \mathrm{ng} / \mathrm{mL}$ of HGF for $96 \mathrm{~h}$ in both cell lines.

On the other hand, PHA665752 has been shown to inhibit cell proliferation in some other tumor types [21, 27]. Therefore, we assumed that the inhibition of c-MET activation by PHA665752 would also reduce cell proliferation in UM. Indeed, our data show that compared with vehicle control (DMSO), the treatment of cancer cells with various concentration of PHA665752 decreased the number of viable UM cells from $48 \mathrm{~h}$ onwards at dose-dependent manner (Figure 1B) in both M17 and SP6.5 cells. A slight difference was observed in the responding dose between two cell lines. The number of viable cells dropped dramatically at $2 \mathrm{mM} / \mathrm{L}$ for M17 and $5 \mathrm{mM} / \mathrm{L}$ onwards for SP6.5. Therefore, M17 is a little bit more sensitive than SP6.5 to PHA665752.

HGF stimulates cell motility in UM cells. Moreover, HGF has been demonstrated to be associated with metastasis in cell lines and animal models [36-38]. Therefore, we examined cell mobile ability induced by HGF. The effect of HGF on cell motility was assessed using routine artificial wound closure and Transwell migration assays. As shown in Figure 2A, 2B, when a wound was introduced into subconfluent cells, more cells migrated across the wound in cells exposed to HGF than in control cells in both M17 and SP6.5 from 24 to 72 hours. At 72 hours, the wounds were completely closed by migrated M17 and SP6.5 cells. Similar induction effect on migration was also observed by Transwell assay (Figure 2C). Moreover, HGF/Met signaling has been shown to promote cell invasion in various cancer cells, including UM [23]. Therefore, we de- 

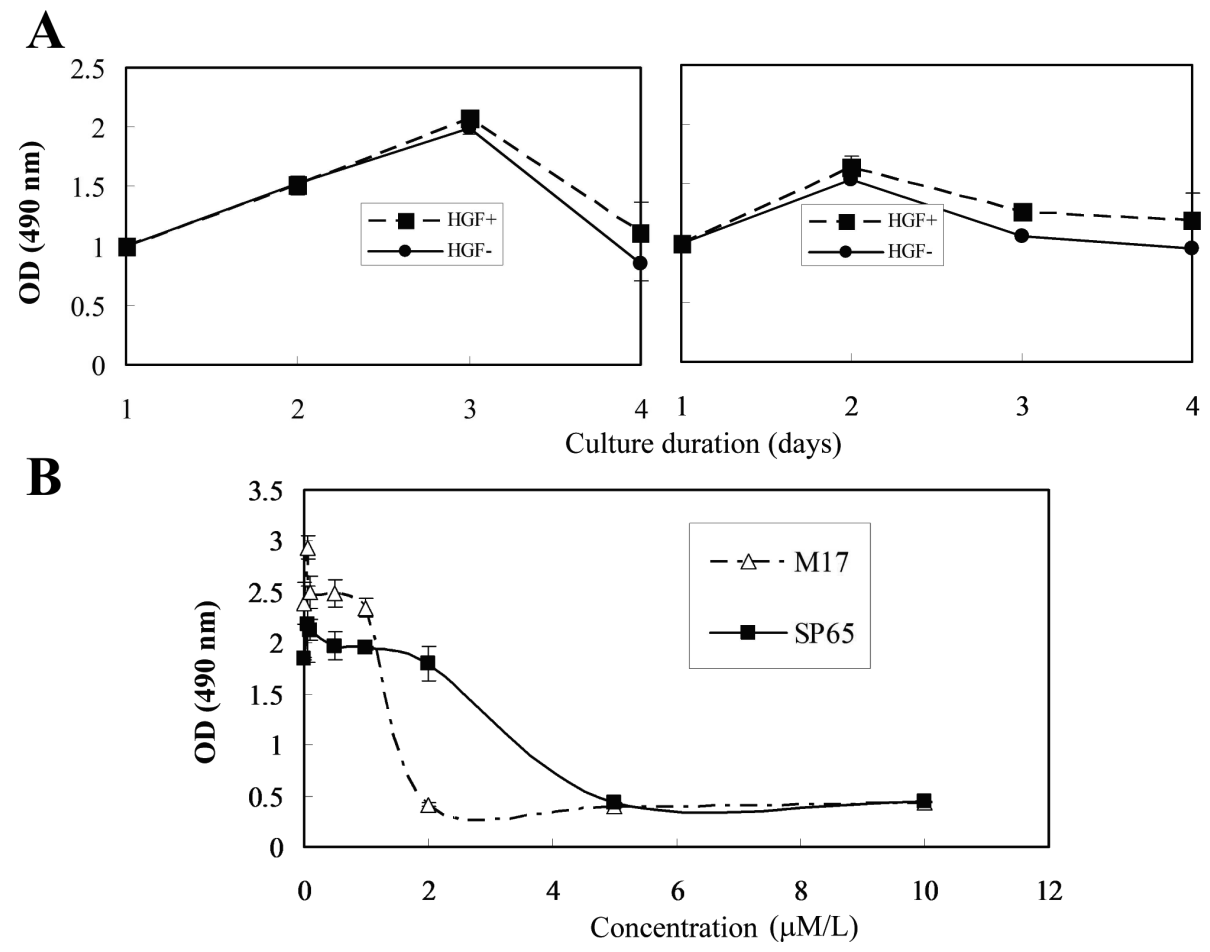

Figure 1. Effects of HGF or PHA665752 on UM cell growth. (A) HGF promoted cell proliferation with very minor effect (left, M17; right, SP6.5). Cells were treated with HGF (40 ng/mL) and cultured for the duration indicated. (B) Cells were treated with the indicated concentration of PHA665752 and cultured for 3 days. The absorbance at $490 \mathrm{~nm}$ is presented as the mean \pm SEM of triplicates. At least three independent experiments were performed.

termined HGF effects on cell invasion of UM cells by Matrigel cell invasion. Our data show that HGF treatment induced a significant increase in the number of cells detected on the underside of the filter (Figure 3). Therefore, they suggest that HGF significantly stimulates cell motility, such as migration and invasion in M17 and SP6.5 cells.

PHA665752 inhibits HGF-mediated UM migration. Similarly, the effect of c-MET inhibition by PHA665752 on cell migration was assessed. To minimize the inhibitory effects on cell survival, $1 \mathrm{mM} / \mathrm{L}$ of PHA665752 was used for cell migration and invasion assays. We found that the addition of PHA665752 resulted in significantly less HGF-treated M17 and SP6.5 cells migrating into the gap (Figure 2A and 2B) or through a porous membrane (Figure $2 \mathrm{C}$ ). To analyze whether PI3-kinase activity is necessary for HGF-induced cell invasion, we performed parallel experiments in the presence of the PI3K inhibitor LY294002, because the role of PI3K in mediating HGF-induced motility has been shown previously [30]. It was observed that PI $3 \mathrm{~K}$ inhibition suppressed the closure of the gap (Figure 2A and 2B). Similar results were obtained in Transwell assays by analyzing the cells migrating through a porous membrane (Figure $2 \mathrm{C}$ ). The treatment of cells with PHA665752 or LY294002 resulted in a decrease in the number of cells migrating into the gap or through a porous membrane toward HGF-containing media when compared to DMSOtreated controls. Therefore, our above data indicate that similar to the effects of LY294002 on cells, PHA665752 treatment abolishes the migratory ability of cells induced by HGF.

PHA665752 inhibits HGF-mediated invasion in UM. The effect of c-MET inhibition by PHA665752 on cell invasion was also assessed. The data show that PHA665752 significantly retarded the rate of invasion (Figure 3) in M17 and SP6.5 cells. The ability of cell invasion correlates with their motility observed in the migration assay in UM cell lines in Figure 2. Similarly, $20 \mu \mathrm{M}$ LY294002 partially abolished HGF-induced invasion of M17 and SP6.5 cells (Figure 3). Taken together, these above results demonstrated that PHA665752 inhibits cell motility induced by HGF through reducing the ability of migration and invasion of cells.

PHA665752 inhibits HGF-induced phosphorylation of c-MET and AKT. Cell motility and invasion can be influenced by phosphorylation of a variety of key regulators of signal transduction pathways, such as c-MET, ERK1/2 and PI3K/ AKT [39]. Our previous data has also shown the requirement of c-MET and PI3K/AKT activation for tumor cell migration induced by HGF in these two UM cell lines [30]. We therefore analyzed the phosphorylation status of c-MET, AKT, and ERK1/2 in these cells. As shown in Figure 4A and B, their expression levels are at low, very low and moderate, respectively before treatment (the first lane in Figure 4A and 4B). We found that HGF treatment induced the phosphorylation of c-MET and especially AKT, but not ERK1/2 (second lane 
A

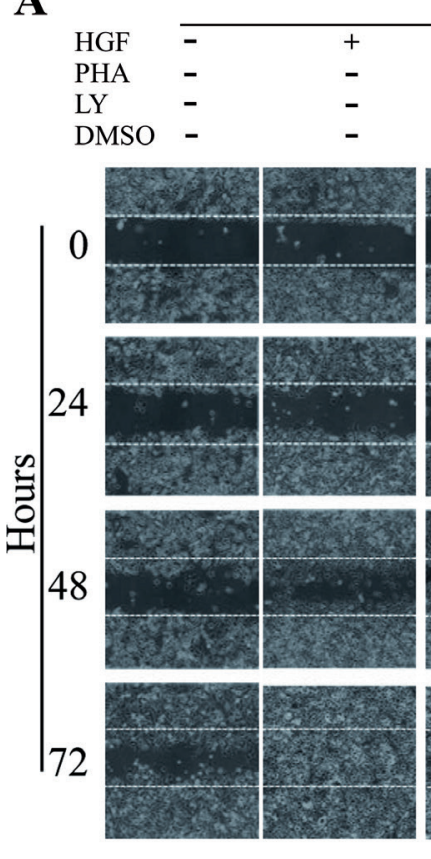

M17
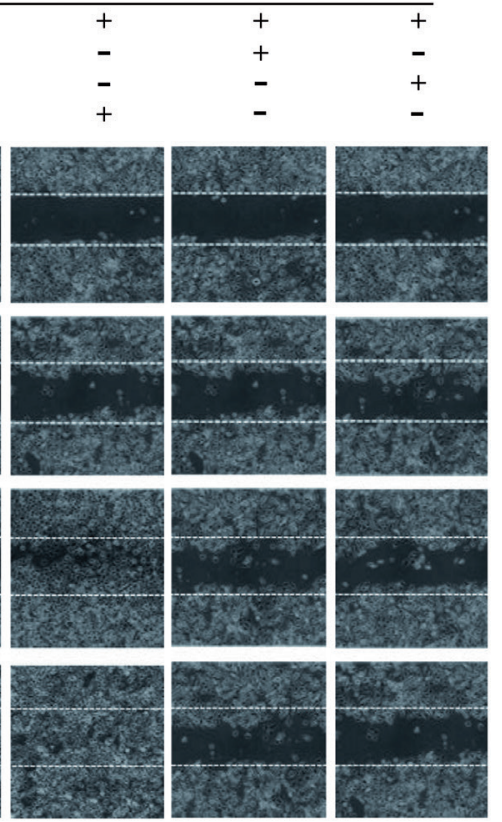

B
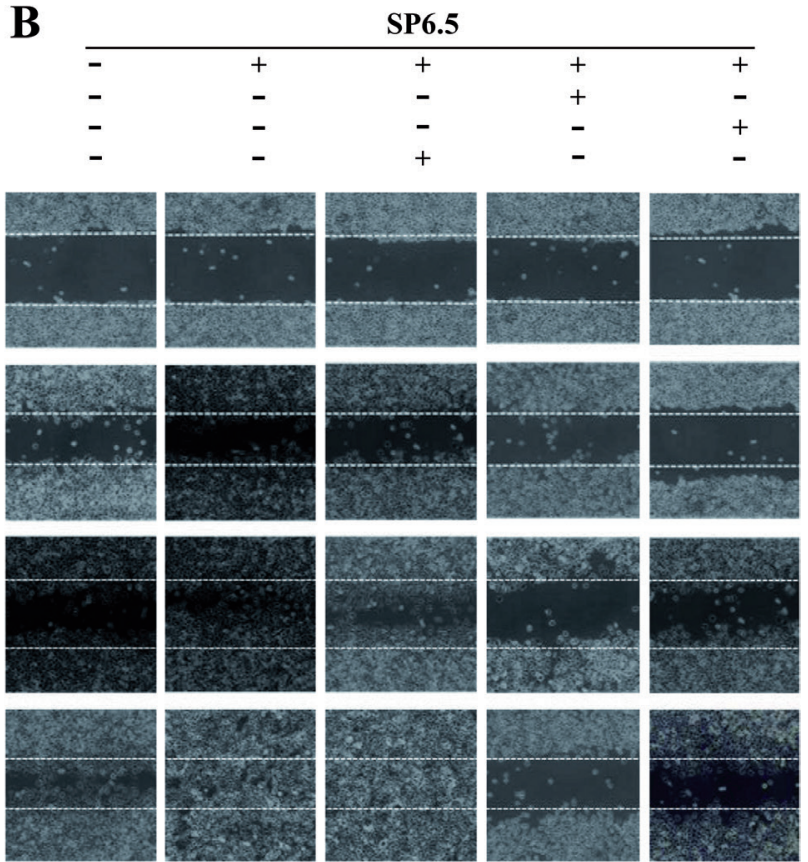

C
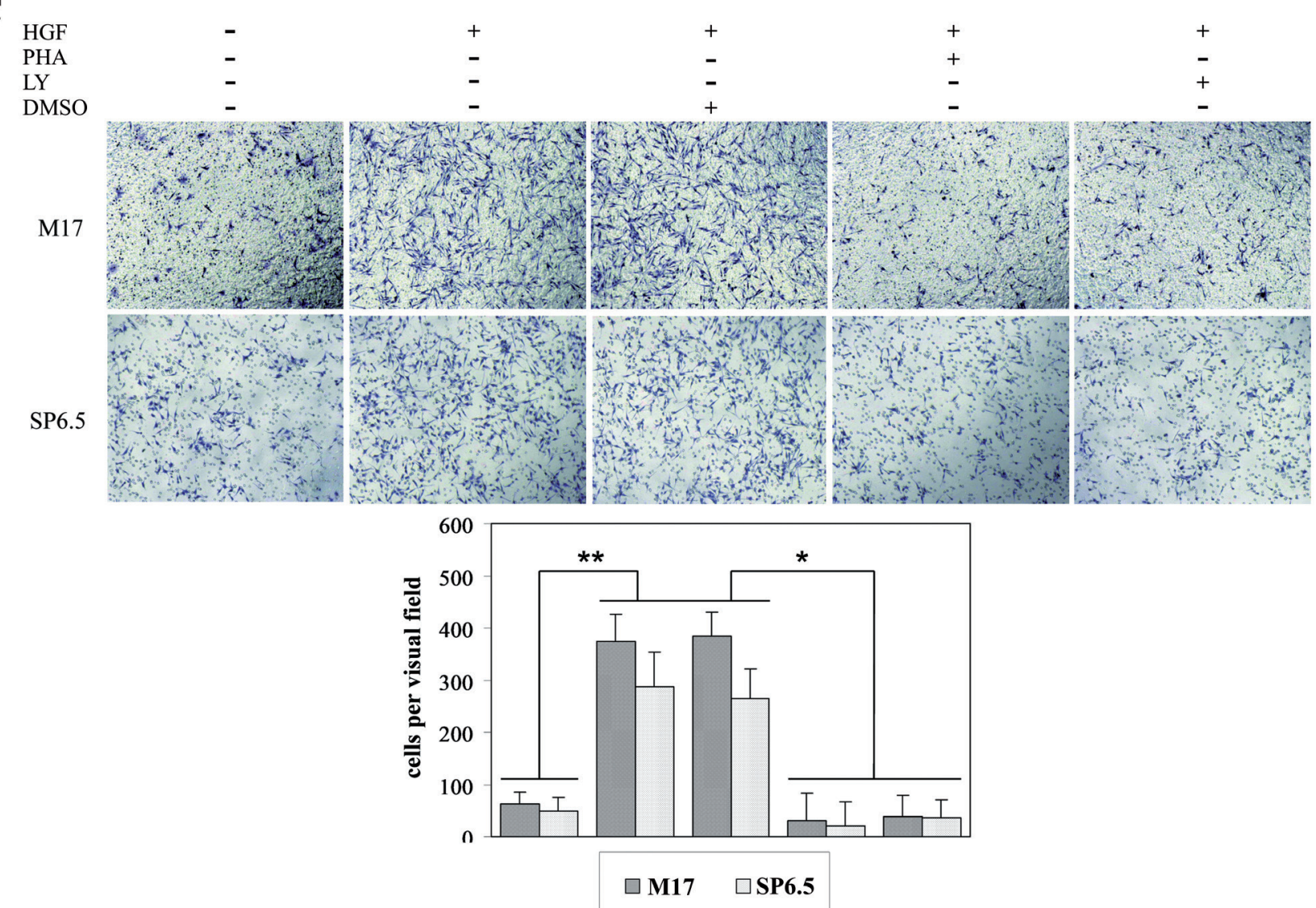

Figure 2. Effects of PHA665752 or LY294002 on HGF-induced cell migration in M17 (A) and SP6.5 cells (B) by wound closure and by Transwell (C) assays. HGF: 40 ng/mL; PHA: PHA665752, $1 \mu$ M; LY: LY294002, $20 \mu$; magnification, $\times 100$. Data presented are representative areas from triplicates with at least three independent experiments. HGF: 40 ng/mL; PHA: PHA665752, $1 \mu$ M; LY: LY294002, $20 \mu$ M. Data are mean \pm SD. ${ }^{* *}, p<0.01 ;{ }^{*}, p<0.05$. 

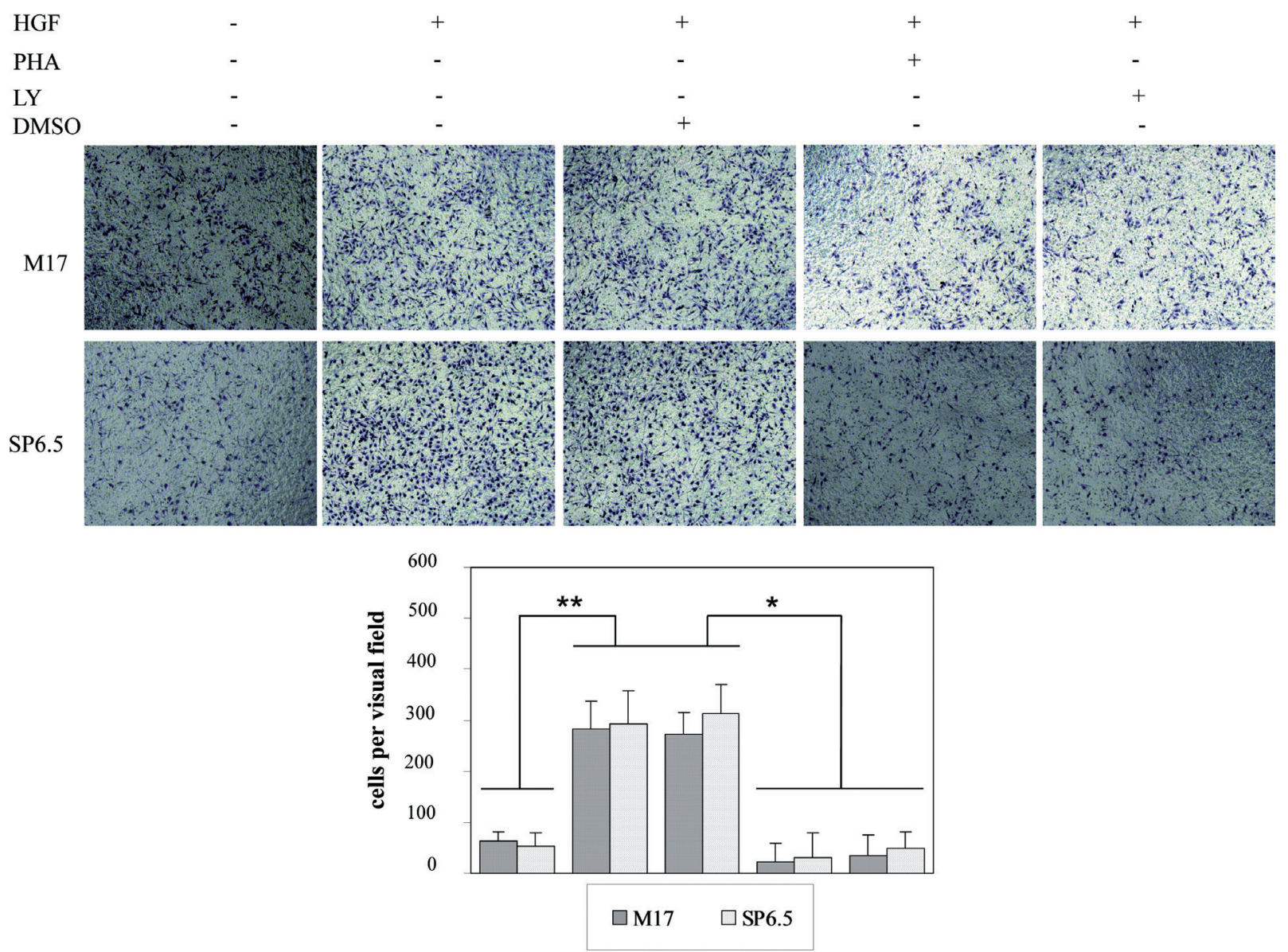

Figure 3. Effects of PHA665752 or LY294002 on HGF-induced cell invasion in UM cell lines. The upper panels are representative results from triplicates. The lower panels are the representative quantification of cells that had invaded through the pores from five independent visual fields using a 20x microscope objective. Each group of columns corresponds to the treatment in the upper panel respectively. HGF: 40 ng/mL; PHA: PHA665752, $1 \mu$ M; LY: LY294002, $20 \mu \mathrm{M}$. Data are mean \pm SD. ${ }^{* *}, p<0.01 ;{ }^{*}, p<0.05$.

in Figure 4A and 4B). Furthermore, PHA665752 treatment efficiently blocked c-MET phosphorylation induced by HGF in a dose dependent manner with concentration ranging from 1 to $10 \mu \mathrm{M}$ of PHA665752, particularly in M17 cells. Moreover, PHA665752 has an even more obvious inhibitory effect on AKT than on c-MET. The phosphorylation of AKT was markedly diminished at $1 \mu \mathrm{M}$, completely or nearly completely inhibited at $5 \mu \mathrm{M}$ and was essentially undetectable at $10 \mu \mathrm{M}$ in both cell lines (Figure 4A and 4B). Furthermore, consistent with the phosphorylation, while HGF treatment induced the translocation of c-MET into the nucleus, PHA665752 prevents the redistribution of c-MET into the nucleus induced by HGF in both cell lines, as shown in Figure 5A. Moreover, similar results were obtained using special antibody against phosphorylated c-MET in these cell lines, as shown in Figure 5B. Taken together, these results showed that both c-MET and AKT were phosphorylated in response to HGF treatment, and the translocation of c-MET and p-c-MET into the nucleus was attenuated by PHA665752 through inhibiting the phospho- rylation of c-MET in these two UM cell lines. Therefore, our data suggest that PHA665752 is a viable strategy to inhibit c-MET activity induced by HGF in UM.

On the other hand, inhibition of PI3K with LY294002 at $20 \mu \mathrm{M}$ completely abolished HGF-induced phosphorylation of AKT (Figure 4C), which is correlated with a decreased numbers of migrated (Figure 2) and invaded (Figure 3) cells in both M17 and SP6.5 cells. These results indicate that blocking PI3K/AKT pathway by LY294002 contributes to inhibiting HGF-induced cell motility. Given that PHA665752 also inhibited AKT phosphorylation induced by HGF in M17 and SP6.5 cells in similar ways, in combination with our previous findings that the activation of $\mathrm{c}-\mathrm{MET}$ and PI3K/AKT is required for tumor cell migration induced by HGF in these two UM cell lines [30], we conclude that it is highly likely that PI3K/AKT signaling mediates these effects induced by c-MET inhibition of PHA665752.

PHA665752 reduces tumor size in nude mice. As in vitro data demonstrate that PHA665752 effectively targeted 

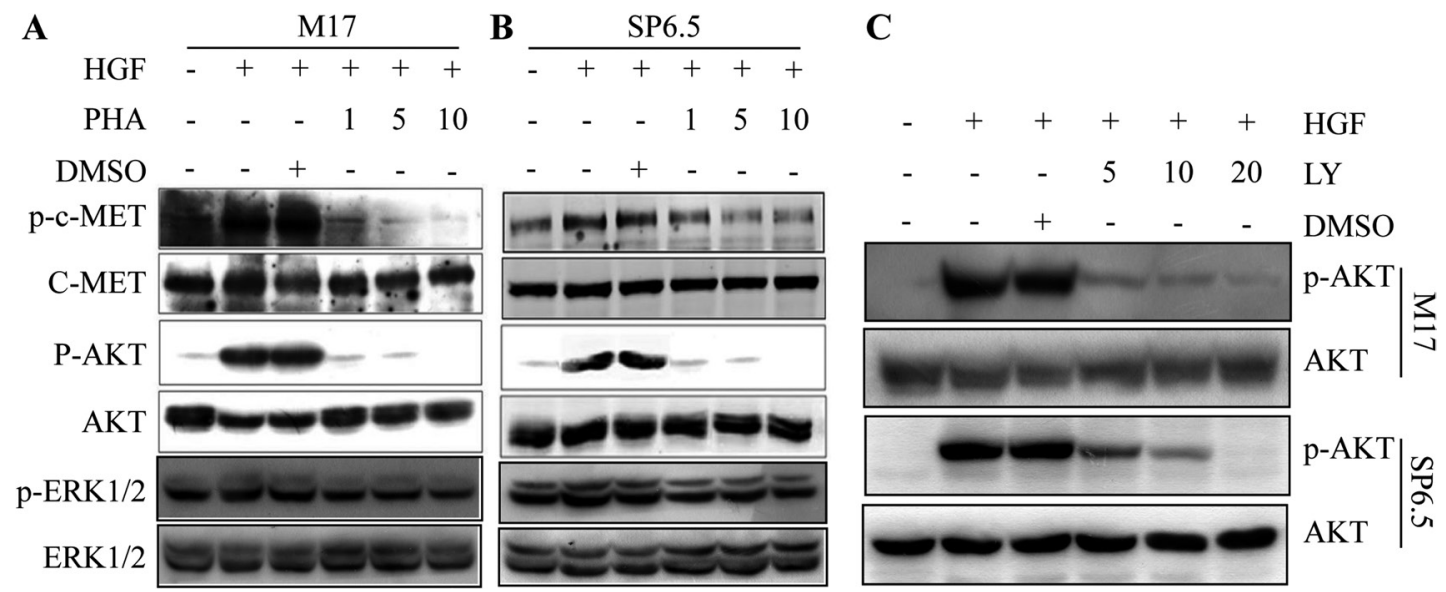

Figure 4. Effects of PHA665752 or LY294002 on HGF-induced phosphorylation of c-MET and AKT. M17 (A) and SP6.5 (B) cells were exposed to the indicated concentrations of PHA665752, and M17 and SP6.5 to LY294002 (C) for 4 h. These cells were then stimulated with HGF (40 ng/mL) for $30 \mathrm{~min}$.

c-MET and downstream PI3K/AKT pathways, we investigated if c-MET inhibition is capable of suppressing tumor growth in vivo. Our results showed that PHA665752 administration significantly inhibited the tumor growth of M17 (Figure 6A) and SP6.5 (Figure 6B) in xenograft models. In addition, PHA665752 administration inhibited the phosphorylation of both c-MET and AKT in tumor tissues of SP6.5 and M17 by immunohistochemical analysis (Figure 7). Hence, the data from in vivo study further support our conclusion from in vitro experiments.

\section{Discussion}

UM is the most common intraocular tumor in adults and accounts for $5 \%$ of all melanomas [1]. Ninety percent of UM metastasizes to the liver along a hematogenous route. Once metastasized, there is no effective therapy, with average survival of 2 to 8 months [4]. The extremely high incidence for liver metastases suggests an importance to study the homing pathways of metastatic tumor cells, which could provide potential for therapeutic intervention of UM [1]. One of the promising pathways is the HGF/c-MET, whose targeting drugs have been approved recently to apply to cancers, such as GIST (gastrointestinal stromal tumor) and RCC (renal cell carcinoma) [13]. However, in this regard, little information is available on $\mathrm{HGF} / \mathrm{c}-\mathrm{MET}$ pathway in UM. Here we present our study of the effects of a small molecule PHA665752, the specific inhibitor of c-MET, the receptor of HGF/c-MET pathway on UM. Our in vitro and in vivo results demonstrated that PHA665752 effectively suppressed cell proliferation, HGF-mediated migration and invasion through inhibiting HGF-induced c-MET phosphorylation, via blocking PI3K/ AKT signaling pathway in M17 and SP6.5 UM cells. Therefore, our present study provides the therapeutic potential of PHA665752 by targeting c-MET to inhibit cell motility in UM.
Notably, we found that HGF seems not to stimulate the cell proliferation, instead, induce cell motility compared to the control in our experiments (Figure 1). This is not surprising, because the motility-inducing nature of HGF/MET has been well-documented at various levels. The receptor c-MET was renamed from an initial name for an oncoprotein and represents metastasis [37, 40]. HGF treatment of hypoxic cancer cells induces synergistic increase in cell migration [41]. Moreover, over-expression of MET and/or HGF in human and mouse cell lines promotes the induction of metastatic tumors in different organs, such as in the lung, heart, diaphragm, salivary gland and retroperitoneum of nude mice [37]. Transgenic mice with over-expression of HGF or MET tend to develop a variety of histologically distinct metastatic tumors with both mesenchymal and epithelial origin, including the mammary gland, skeletal muscle, lung and melanocytes [36, 38]. It has been summarized the role of $\mathrm{HGF} / \mathrm{c}-\mathrm{MET}$ axis in the regulation of various stages in metastatic process, including the stimulation of the dissociation of tumor cells from primary site, the mediation of matrix degradation and invasion, and the promotion of the interaction of tumor cells with blood vessels, extravasation and homing cite [42].

Our results also showed that c-MET localizes to the nucleus after HGF treatment in both M17 and SP6.5 cell lines. However, previous results have showed the translocation of c-MET from cell membrane periphery to the cytoplasm in SP6.5 [30]. This discrepancy could partially be caused by the use of different antibodies, because the different subcellular stainings of c-MET have been detected under the same conditions by using different antibodies [43]. On the other hand, it has been reported that PHA665752 causes a minor reduction in EGF-induced migration in high c-Met/EGFRexpressing UM cell line C918 [21]. Therefore, it is possible that the overall inhibitory effects of PHA665752 on UM cell migration in this study could include those through EGFR, 
despite of the fact that the selectivity of PHA665752 on cMET is much greater than that on EGFR [27]. Even though this potent off-target effects, PHA665752 has relatively quite low IC50 with $0.018 \sim 0.05 \mathrm{mM}$ [27], compared with that of
MK-8033 with 8.5 19.2 mM [44] in a series of cell lines. In order to lower the drug concentration, MK-8033 has been employed to inhibit cell growth in UM together with an MEK inhibitor [26].
A

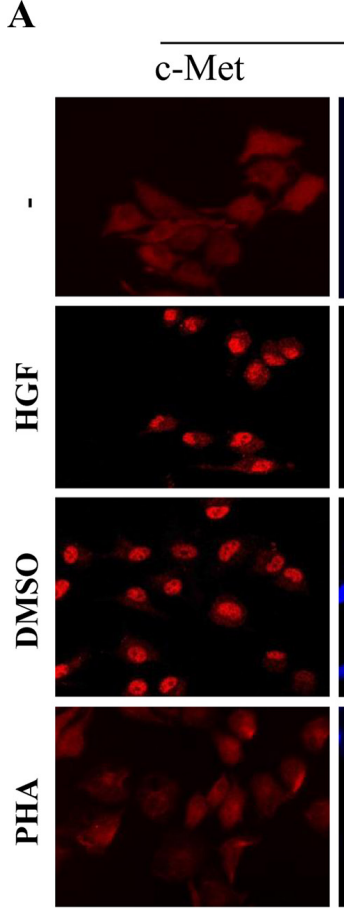

B

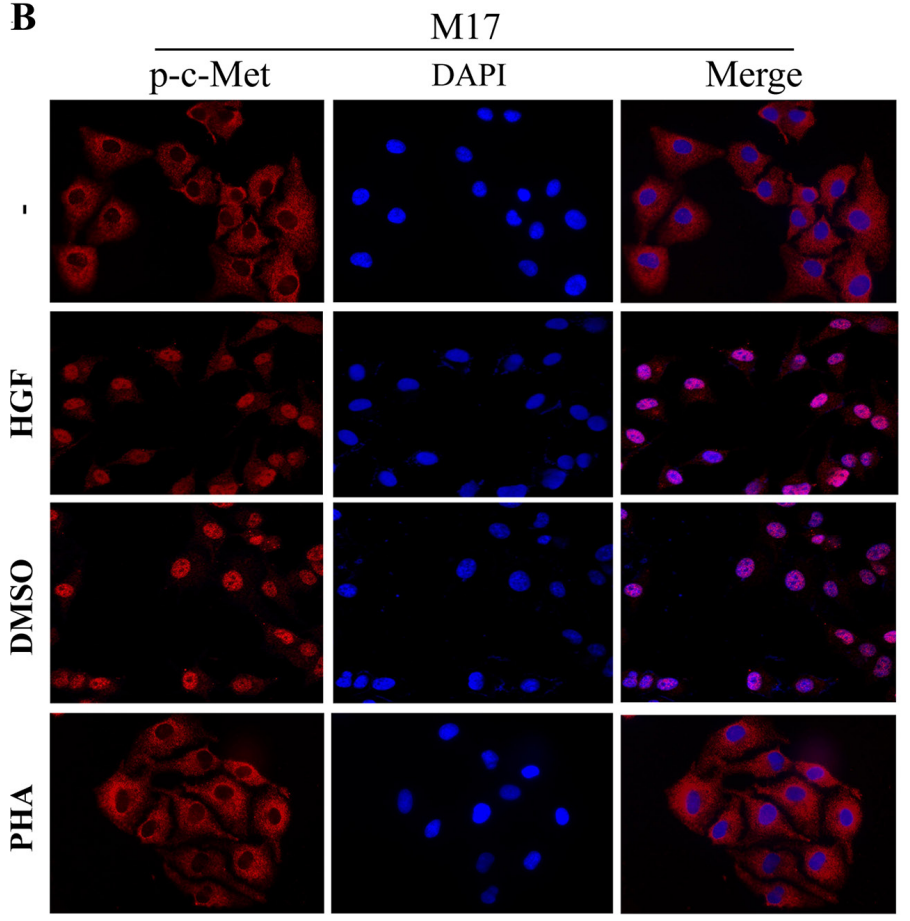

M17

DAPI
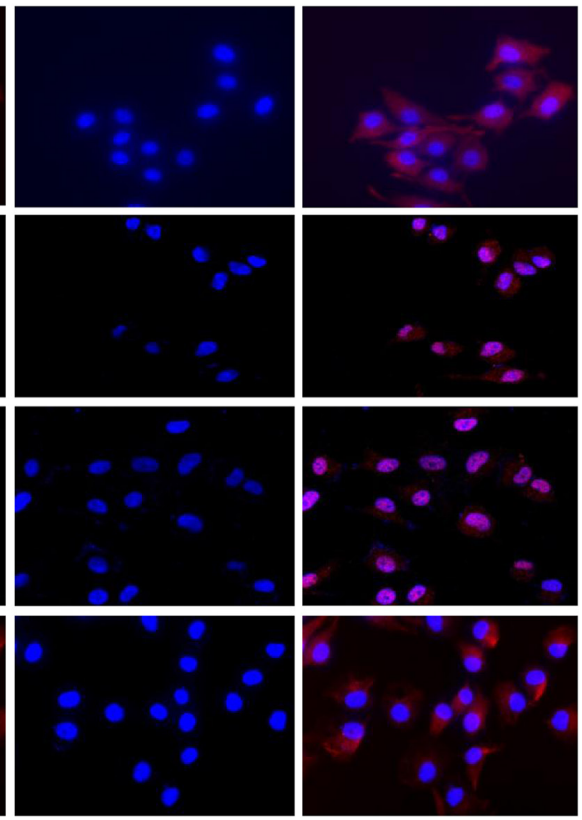
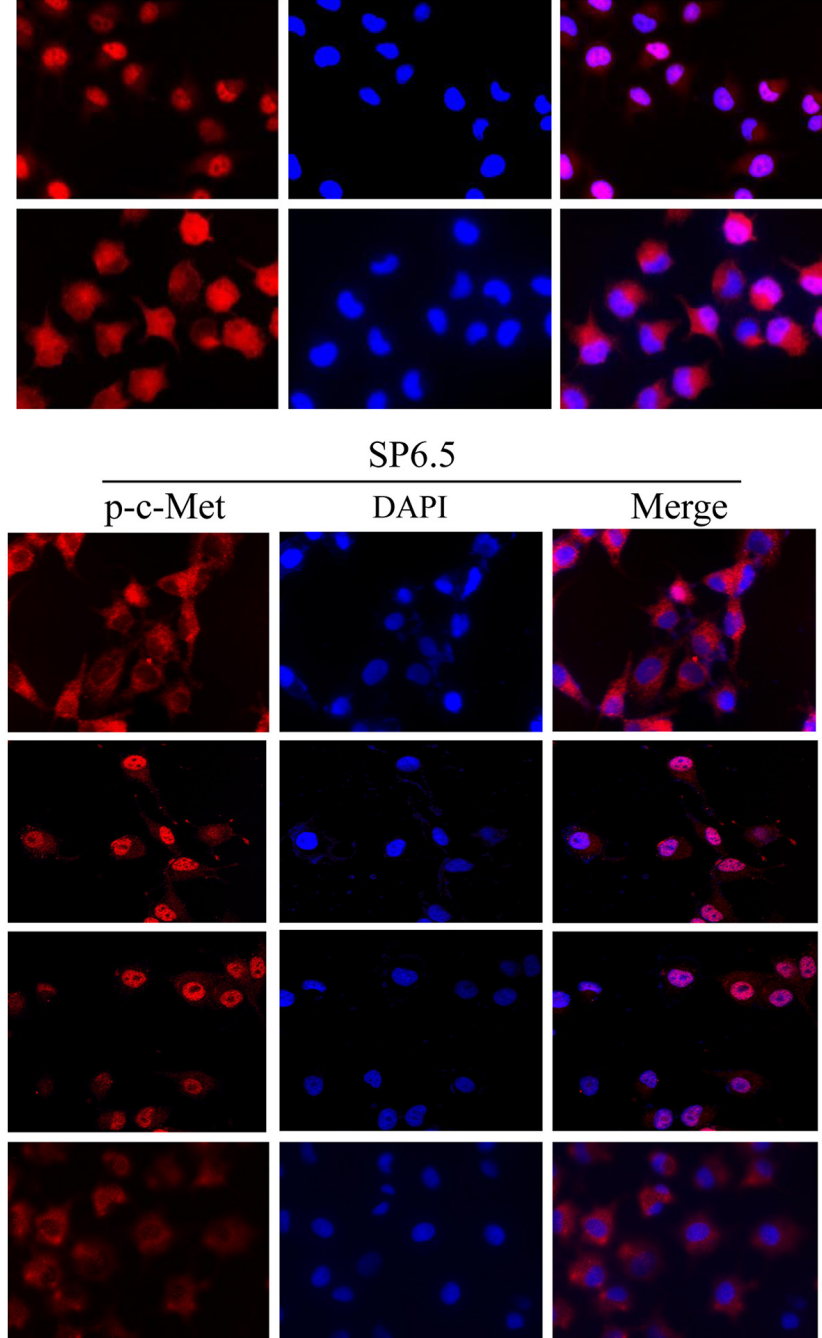

SP6.5

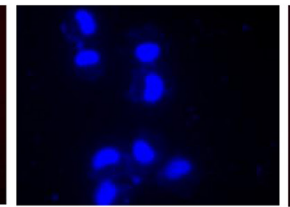

Merge
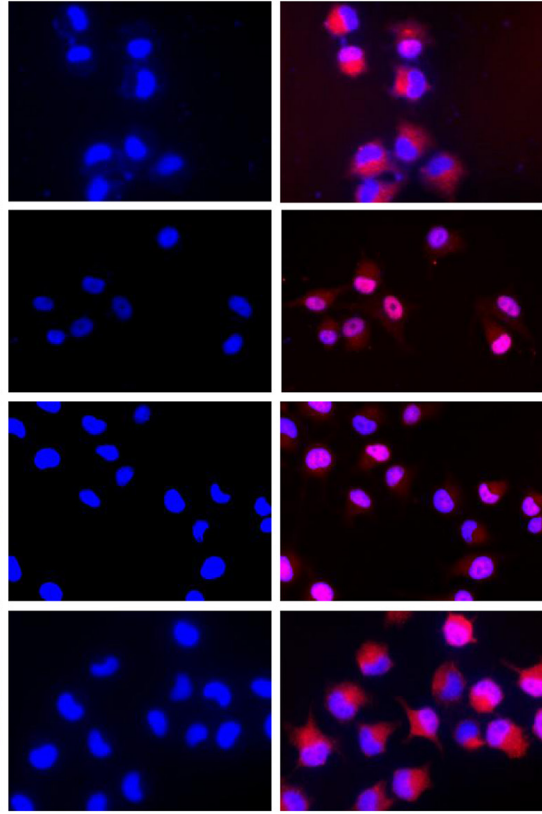

SP6.5
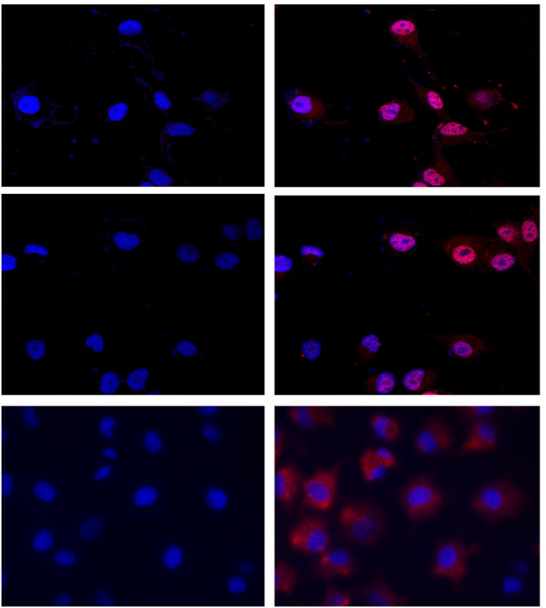

Figure 5. Effects of PHA665752 on HGF-induced translocation of c-MET and p-c-MET. M17 and SP6.5 cells were exposed to $1 \mu M / L$ of PHA665752 for $4 \mathrm{~h}$ and then stimulated with HGF $(40 \mathrm{ng} / \mathrm{mL})$ for $30 \mathrm{~min}$. The cellular redistribution of c-MET (A) and p-c-MET (B) was examined after treatments. Cy3, c-Met or p-c-MET (left column); DAPI, nucleus (middle column); DAPI/c-Met, merged (right column). 


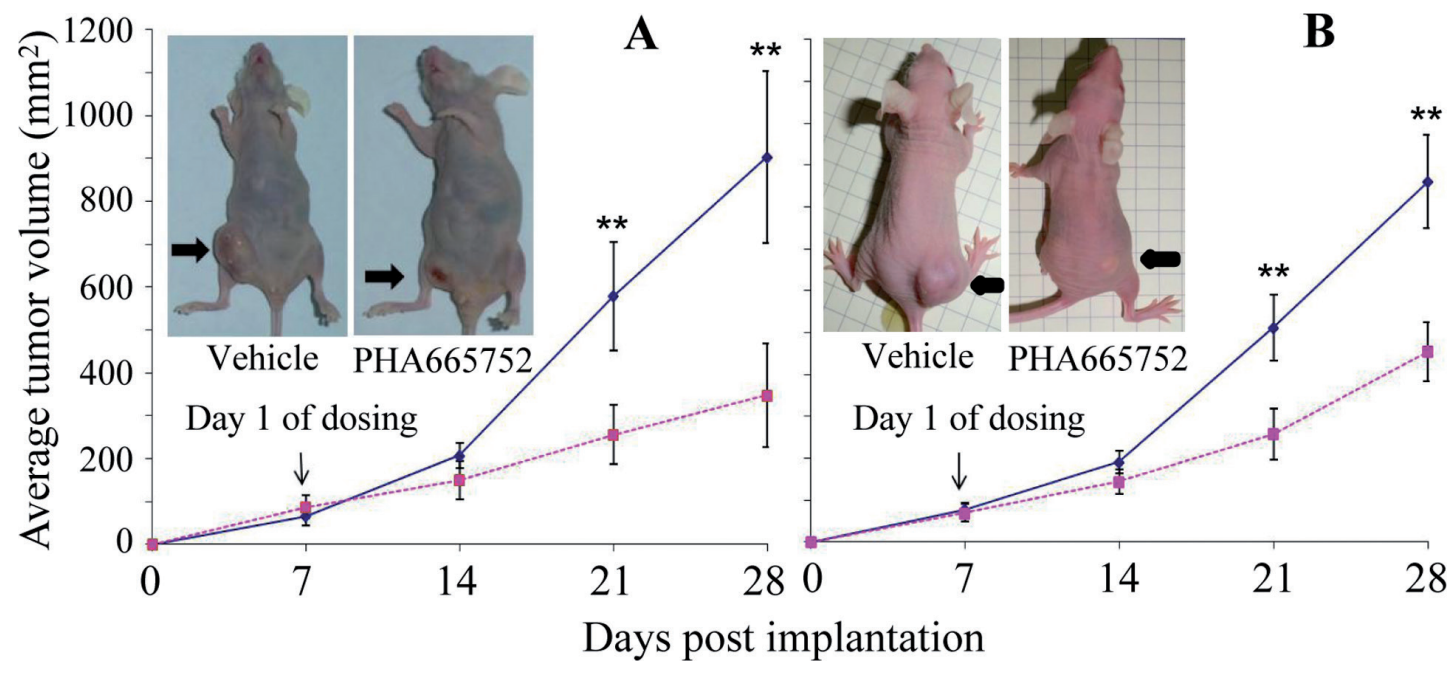

Figure 6. In vivo inhibition of tumor growth of M17 (A) and SP6.5 (B) by PHA665752. Representative pictures demonstrate the tumors at the end point (arrow), with tumor volume reported as mean \pm SEM. ${ }^{* *} p<0.01 ; \mathrm{N}=5-10 /$ group.

On the other hand, metastasis is regulated by a variety of signal pathways, such as p38 MAPK in various cancers [45]. Specially, studies have demonstrated that proliferation and motility of cells in some contexts appear exclusive and that the status of activated p38 appears critical in cellular decisions regarding proliferation and motility in responding to various stimuli. In our present study, HGF treatment did not alter proliferation but promoted cell motility, which may be associated with the unchanged phosphorylation level of $\mathrm{p} 38$, as seen in our previous report [30]. Similar phenomena have also been observed in some other studies. For example, it has been found that migration and invasion of cells are suppressed but no effect has been detected on proliferation through the suppression of the phosphorylation of $\mathrm{p} 38$ by inhibition of
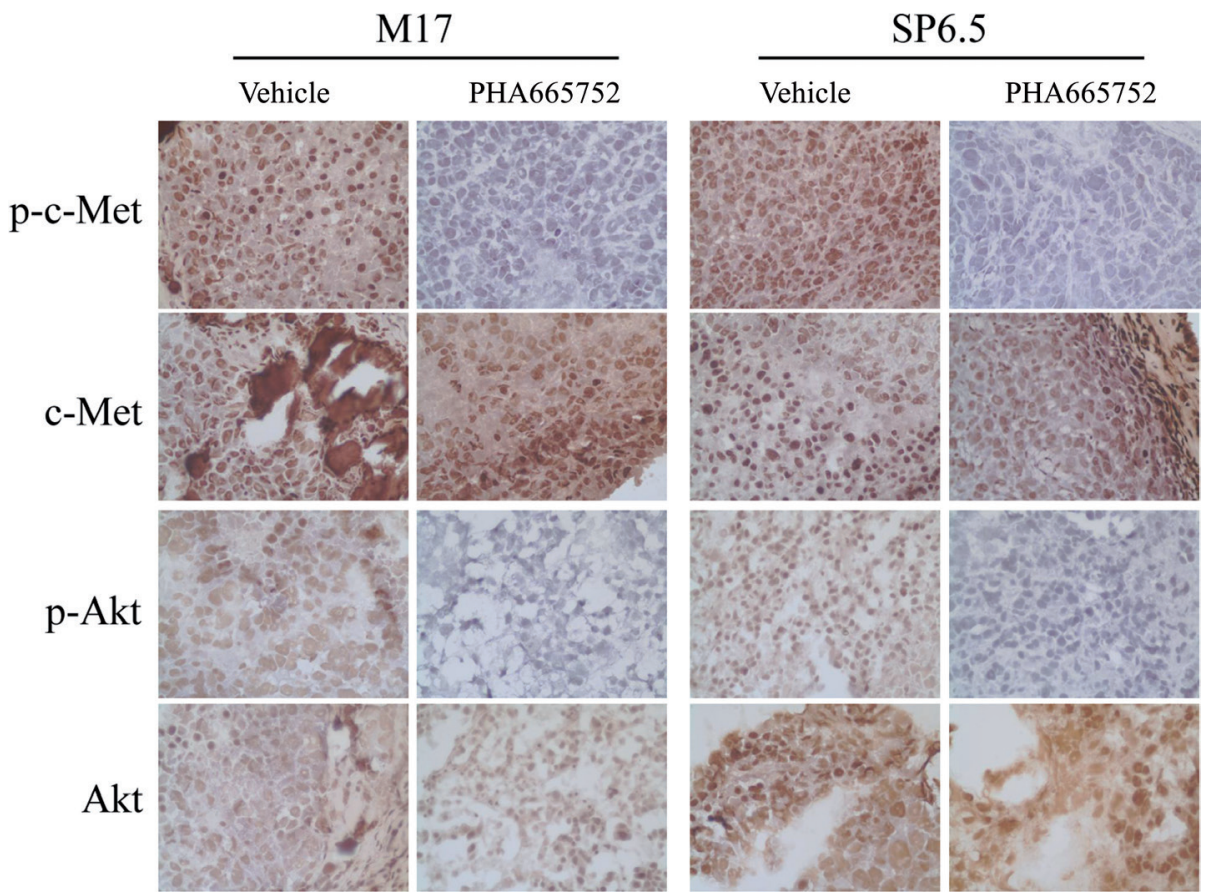

Figure 7. In vivo inhibition of the phosphorylation of both c-MET and AKT by PHA665752. Hematoxylin and eosin (H\&E) staining and immunohistochemical analysis using anti-phospho-c-MET (Y1234/1235) and anti-phospho-AKT (S473) antibody in tumors of nude mice administered with PHA665752 or vehicle (magnification $\times 400)$. 
L1CAM (L1 cell adhesion molecule) by siRNA in melanoma B16F10 cells [46], by p38 inhibitor SB203580 in human melanoma cell line MeWo cells [47], by WAVE3 siRNA in human breast cancer cell line MDA-MB-231 cells [39] and by p38 inhibitor SB203580 in human pancreatic carcinoma cell line PANC-1 cell [48]. Conversely, cell proliferation but not motility is promoted by HGF-activated p38 in mouse melanomas cell line 37-32 [35]. Hence, it seems that the increase of activated p38 is to promote cell proliferation, the reduction of active p38 to inhibit cell motility and no change of phosphorylated p38 to promote motility of cells in response to some growth factors and other treatments.

Furthermore, HGF treatment enhanced the phosphorylation level of AKT and induced cell motility in M17 and SP6.5 cells in the present study. In contrast, PI3K inhibitor LY294002 significantly inhibited not only the activation of AKT but also cell motility induced by HGF. The activated PI3K/AKT pathway has been demonstrated to be required for the HGF-induced migration in UM, because the treatment of PI3K inhibitor LY294002 efficiently impeded HGF-induced migration [30]. Similarly to that of LY294002, the treatment of PHA665752 obviously suppressed not only the phosphorylation of AKT but tumor cell motility as well induced by HGF. Moreover, we found that the treatment of these UM cells with HGF and/or PHA665752 did not affect the expression levels and/or activity of some motility- or metastasis-related molecules, such as MMP2, MMP9, uPAR, FAK, STAT3 and P21-activated kinase-1(PAK1) (data not shown). On the other hand, a lot of similar in vitro and in vivo studies have also demonstrated the requirement of PI3K/AKT pathway in HGF-induced motility in other cancers, such as nasopharyngeal cancer [49], lung [50, 51], breast [50], liver cancer [52, 53] and cholangiocarcinoma [54]. Therefore, the inhibitory effects of PHA665752 on HGF-stimulated motility are highly likely through PI3K/AKT pathway in UM of this study.

Therefore, we demonstrated that PHA665752 is an effective c-MET inhibitor to reduce cell migration and invasion induced by HGF via blocking PI3K/AKT pathway in UM through in vitro and in vivo experiments. This is of particular importance for UM, because nearly $50 \%$ of patients diagnosed with primary posterior UM will develop metastasis, mostly in liver, producing highly fatal cancer $[4,5]$. Therefore, this study suggests that targeting $\mathrm{HGF} / \mathrm{c}-\mathrm{MET}$ pathway could also be a novel therapy strategy for patients with highly metastatic and fatal UM. PHA665752 could be a promising therapeutic option for UM metastasis by preventing cell motility. Further studies are needed to characterize the prevention potential of PHA665752 against UM cell metastasis in animal models.

Acknowledgements: This work was supported by a grant from the National Natural Science Foundation of China (grant no. 81201657), and a grant from Jiangsu Province University Natural Science Research Program (grant no. 15KJB360001). We thank Dr Hou Qiang (Wenzhou Medical University, China) for his critical reading of the manuscript. We declare no potential conflicts of interest.

\section{References}

[1] SINGH AD, BERGMAN L, SEREGARD S. Uveal melanoma: Epidemiologic aspects. Ophthalmol Clin North Am 2005; 18: 75-84. https://doi.org/10.1016/j.ohc.2004.07.002

[2] ARNESEN K. The neural crest origin of uveal melanomas. Int Ophthalmol 1985; 7: 143-147. https://doi.org/10.1007/ $\underline{B F 00128360}$

[3] DAMATO BE. Treatment selection for uveal melanoma. Dev Ophthalmol 2012; 49: 16-26. https://doi. org/10.1159/000328251

[4] GRIEWANK KG, MURALI R. Pathology and genetics of uveal melanoma. Pathology 2013; 45: 18-27. https://doi. org/10.1097/PAT.0b013e32835c6505

[5] MUNZENRIDER JE. Uveal melanomas. Conservation treatment. Hematol Oncol Clin North Am 2001; 15: 389-402. https://doi.org/10.1016/S0889-8588(05)70219-7

[6] PATEL M, SMYTH E, CHAPMAN PB, WOLCHOK JD, SCHWARTZ GK et al. Therapeutic implications of the emerging molecular biology of uveal melanoma. Clin Cancer 2011; 17: 2087-2100. https://doi.org/10.1158/1078-0432.CCR-10$\underline{3169}$

[7] WOODMAN SE. Metastatic uveal melanoma: Biology and emerging treatments. Cancer J 2012; 18: 148-152. https://doi. org/10.1097/PPO.0b013e31824bd256

[8] COUPLAND SE, LAKE SL, ZESCHNIGK M, DAMATO BE. Molecular pathology of uveal melanoma. Eye (Lond) 2013; 27: 230-242. https://doi.org/10.1038/eye.2012.255

[9] JUNG KH, PARK BH, HONG SS. Progress in cancer therapy targeting c-met signaling pathway. Arch Pharm Res 2012; 35: 595-604. https://doi.org/10.1007/s12272-012-0402-6

[10] SCAGLIOTTI GV, NOVELLO S, VON PAWEL J. The emerging role of met/hgf inhibitors in oncology. Cancer Treat Rev 2013; 39: 793-801. https://doi.org/10.1016/j.ctrv.2013.02.001

[11] BIRCHMEIER C, BIRCHMEIER W, GHERARDI E, VANDE WOUDE GF. Met, metastasis, motility and more. Nat Rev Mol Cell Biol 2003; 4: 915-925. https://doi.org/10.1038/nrm1261

[12] COMOGLIO PM. Pathway specificity for met signalling. Nat Cell Biol 2001; 3: E161-162. https://doi.org/10.1038/35083116

[13] CUI JJ. Targeting receptor tyrosine kinase met in cancer: Small molecule inhibitors and clinical progress. J Med Chem 2014; 57: 4427-4453. https://doi.org/10.1021/jm401427c

[14] SHOJAEI F, SIMMONS BH, LEE JH, LAPPIN PB, CHRISTENSEN JG. Hgf/c-met pathway is one of the mediators of sunitinib-induced tumor cell type-dependent metastasis. Cancer Lett 2012; 320: 48-55. https://doi.org/10.1016/j.canlet.2012.01.026

[15] CORSO S, GIORDANO S. Cell-autonomous and non-cellautonomous mechanisms of HGF/MET-driven resistance to targeted therapies: from basic research to a clinical perspective. Cancer Discov 2013; 3: 978-992. https://doi.org/10.1158/2159$\underline{\text { 8290.CD-13-0040 }}$

[16] CECCHI F, RABE DC, BOTTARO DP. Targeting the hgf/ met signalling pathway in cancer. Eur J Cancer 2010; 46: 1260-1270. https://doi.org/10.1016/j.ejca.2010.02.028

[17] ABDEL-RAHMAN MH, BORU G, MASSENGILL J, SALEM MM, DAVIDORF FH. Met oncogene inhibition as a potential 
target of therapy for uveal melanomas. Invest Ophthalmol Vis Sci 2010; 51: 3333-3339. https://doi.org/10.1167/iovs.09-4801

[18] BAKALIAN S, MARSHALL JC, LOGAN P, FAINGOLD D, MALONEY S et al. Molecular pathways mediating liver metastasis in patients with uveal melanoma. Clin Cancer Res 2008; 14: 951-956. https://doi.org/10.1158/1078-0432. CCR-06-2630

[19] GARDNER FP, SERIE DJ, SALOMAO DR, WU KJ, MARKOVIC SN et al. C-met expression in primary and liver metastases in uveal melanoma. Melanoma Res 2014; 24 : 617-620. https://doi.org/10.1097/CMR.0000000000000118

[20] SAMADI AK, COHEN SM, MUKERJI R, CHAGUTURU $\mathrm{V}$, ZHANG X et al. Natural withanolide withaferin a induces apoptosis in uveal melanoma cells by suppression of akt and c-met activation. Tumour Biol 2012; 33: 1179-1189. https:// doi.org/10.1007/s13277-012-0363-X

[21] WU X, ZHOU J, ROGERS AM, JANNE PA, BENEDETTINI E et al. C-met, epidermal growth factor receptor, and insulinlike growth factor-1 receptor are important for growth in uveal melanoma and independently contribute to migration and metastatic potential. Melanoma Res 2012; 22: 123-132. https://doi.org/10.1097/CMR.0b013e3283507ffd

[22] DI CESARE S, MARSHALL JC, LOGAN P, ANTECKA E, FAINGOLD D et al. Expression and migratory analysis of 5 human uveal melanoma cell lines for CXCL12, CXCL8, CXCL1, AND HGF. J Carcinog 2007; 6: 2.

[23] WOODWARD JK, ELSHAW SR, MURRAY AK, NICHOLS $\mathrm{CE}, \mathrm{CROSS} \mathrm{N}$ et al. Stimulation and inhibition of uveal melanoma invasion by HGF, GRO, IL-1alpha and TGF-beta. Invest Ophthalmol Vis Sci 2002; 43: 3144-3152.

[24] SURRIGA O, RAJASEKHAR VK, AMBROSINI G, DOGAN Y, HUANG R et al. Crizotinib, a c-met inhibitor, prevents metastasis in a metastatic uveal melanoma model. Mol Cancer Ther 2013; 12: 2817-2826. https://doi.org/10.1158/1535-7163. MCT-13-0499

[25] BLACKHALL F, CAPPUZZO F. Crizotinib: from discovery to accelerated development to front-line treatment. Ann Oncol 2016; 27 Suppl 3: iii35-iii41. https://doi.org/10.1093/annonc/ mdw304

[26] CHATTOPADHYAY C, GRIMM EA, WOODMAN SE. Simultaneous inhibition of the HGF/MET and Erk1/2 pathways affect uveal melanoma cell growth and migration. PLoS One 2014; 9: e83957. https://doi.org/10.1371/journal.pone.0083957

[27] CHRISTENSEN JG, SCHRECK R, BURROWS J, KURUGANTI P, CHAN E et al. A selective small molecule inhibitor of c-met kinase inhibits c-met-dependent phenotypes in vitro and exhibits cytoreductive antitumor activity in vivo. Cancer Res 2003; 63: 7345-7355.

[28] SRIVASTAVA AK, HOLLINGSHEAD MG, WEINER J, NAVAS T, EVRARD YA et al. Pharmacodynamic Response of the MET/HGF Receptor to Small-Molecule Tyrosine Kinase Inhibitors Examined with Validated, Fit-for-Clinic Immunoassays. Clin Cancer Res 2016; 22: 3683-3694. https://doi. org/10.1158/1078-0432.CCR-15-2323

[29] PURI N, KHRAMTSOV A, AHMED S, NALLASURA V, HETZEL JT et al. A selective small molecule inhibitor of c-MET, PHA665752, inhibits tumorigenicity and angiogen- esis in mouse lung cancer xenografts. Cancer Res 2007; 67: 3529-3534. https://doi.org/10.1158/0008-5472.CAN-06-4416

[30] YE M, HU D, TU L, ZHOU X, LU F et al. Involvement of pi3k/ akt signaling pathway in hepatocyte growth factor-induced migration of uveal melanoma cells. Invest Ophthalmol Vis Sci 2008; 49: 497-504. https://doi.org/10.1167/iovs.07-0975

[31] LISKA D, CHEN CT, BACHLEITNER-HOFMANN T, CHRISTENSEN JG, WEISER MR. HGF rescues colorectal cancer cells from EGFR inhibition via MET activation. Clin Cancer Res 2011; 17: 472-482. https://doi.org/10.1158/10780432.CCR-10-0568

[32] ARRIOLA E, CANADAS I, ARUMI-URIA M, DOMINE M, LOPEZ-VILARINO JA et al. Met phosphorylation predicts poor outcome in small cell lung carcinoma and its inhibition blocks hgf-induced effects in met mutant cell lines. Br J Cancer 2011; 105: 814-823. https://doi.org/10.1038/bjc.2011.298

[33] GUESSOUS F, ZHANG Y, DIPIERRO C, MARCINKIEWICZ L, SARKARIA J et al. An orally bioavailable c-met kinase inhibitor potently inhibits brain tumor malignancy and growth. Anticancer Agents Med Chem 2010; 10: 28-35. https://doi. org/10.2174/1871520611009010028

[34] LEE CC, PUTNAM AJ, MIRANTI CK, GUSTAFSON M, WANG LM et al. Overexpression of sprouty 2 inhibits HGF/ SF-mediated cell growth, invasion, migration, and cytokinesis. Oncogene 2004; 23: 5193-5202. https://doi.org/10.1038/ sj.onc. 1207646

[35] RECIO JA, MERLINO G. Hepatocyte growth factor/scatter factor activates proliferation in melanoma cells through p38 MAPK, ATF-2 and cyclin D1. Oncogene 2002; 21: 1000-1008. https://doi.org/10.1038/sj.onc. 1205150

[36] GALLEGO MI, BIERIE B, HENNIGHAUSEN L. Targeted expression of HGF/SF in mouse mammary epithelium leads to metastatic adenosquamous carcinomas through the activation of multiple signal transduction pathways. Oncogene 2003; 22: 8498-8508. https://doi.org/10.1038/sj.onc. 1207063

[37] RONG S, SEGAL S, ANVER M, RESAU JH, VANDE WOUDE GF. Invasiveness and metastasis of NIH 3T3 cells induced by Met-hepatocyte growth factor/scatter factor autocrine stimulation. Proc Natl Acad Sci U S A 1994; 91: 4731-4735. https://doi.org/10.1073/pnas.91.11.4731

[38] TAKAYAMA H, LAROCHELLE WJ, SHARP R, OTSUKA T, KRIEBEL $P$ et al. Diverse tumorigenesis associated with aberrant development in mice overexpressing hepatocyte growth factor/scatter factor. Proc Natl Acad Sci U S A 1997; 94: 701-706. https://doi.org/10.1073/pnas.94.2.701

[39] SOSSEY-ALAOUI K, RANALLI TA, LI X, BAKIN AV, COWELL JK. WAVE3 promotes cell motility and invasion through the regulation of MMP-1, MMP-3, and MMP-9 expression. Exp Cell Res 2005; 308: 135-145. https://doi.org/10.1016/j. yexcr.2005.04.011

[40] GHERARDI E, BIRCHMEIER W, BIRCHMEIER C, VANDE WOUDE G. Targeting MET in cancer: Rationale and progress. Nat Rev Cancer 2012; 12: 89-103. https://doi.org/10.1038/ $\underline{\operatorname{nrc} 3205}$

[41] PENNACCHIETTI S, MICHIELI P, GALLUZZO M, MAZZONE M, GIORDANO S, et al. Hypoxia promotes invasive growth by transcriptional activation of the met protoonco- 
gene. Cancer Cell 2003; 3: 347-361. https://doi.org/10.1016/ S1535-6108(03)00085-0

[42] LESKO E, MAJKA M. The biological role of hgf-met axis in tumor growth and development of metastasis. Front Biosci 2008; 13: 1271-1280. https://doi.org/10.2741/2760

[43] POZNER-MOULIS S, PAPPAS DJ, RIMM DL. Met, the hepatocyte growth factor receptor, localizes to the nucleus in cells at low density, Cancer Res 2006; 66: 7976-7982. https:// doi.org/10.1158/0008-5472.CAN-05-4335

[44] MARCHION DC, BICAKU E, XIONG Y, BOU ZGHEIB $\mathrm{N}, \mathrm{AL}$ SAWAH E et al. A novel c-Met inhibitor, MK8033, synergizes with carboplatin plus paclitaxel to inhibit ovarian cancer cell growth. Oncol Rep 2013; 29: 2011-2018.

[45] KOUL HK, PAL M, KOUL S. Role of p38 MAPK kinase signal transduction in solid tumors. Genes Cancer 2013; 4: 342-359. https://doi.org/10.1177/1947601913507951

[46] YI YS, BAEK KS, CHO JY. L1 cell adhesion molecule induces melanoma cell motility by activation of mitogen-activated protein kinase pathways. Pharmazie 2014; 69: 461-467.

[47] DENKERT C, SIEGERT A, LECLERE A, TURZYNSKI A, HAUPTMANN S. An inhibitor of stress-activated MAPkinases reduces invasion and MMP-2 expression of malignant melanoma cells. Clin Exp Metastasis 2002; 19: 79-85. https:// doi.org/10.1023/A:1013857325012

[48] DREISSIGACKER U, MUELLER MS, UNGER M, SIEGERT $\mathrm{P}$, GENZE F et al. Oncogenic K-Ras down-regulates Rac1 and RhoA activity and enhances migration and invasion of pancreatic carcinoma cells through activation of p38. Cell Signal 2006; 18: 1156-1168. https://doi.org/10.1016/j.cellsig.2005.09.004
[49] ZHOU HY, WAN KF, IP CK, WONG CK, MAK NK et al. Hepatocyte growth factor enhances proteolysis and invasiveness of human nasopharyngeal cancer cells through activation of PI3K and JNK. FEBS Lett 2008; 582: 3415-3422. https:// doi.org/10.1016/j.febslet.2008.09.004

[50] LEE WJ, CHEN WK, WANG CJ, LIN WL, TSENG TH. Apigenin inhibits HGF-promoted invasive growth and metastasis involving blocking PI3K/Akt pathway and beta 4 integrin function in MDA-MB-231 breast cancer cells. Toxicol Appl Pharmacol 2008; 226: 178-191. https://doi.org/10.1016/j.taap.2007.09.013

[51] USATYUK PV, FU P, MOHAN V, EPSHTEIN Y, JACOBSON JR et al. Role of c-Met/phosphatidylinositol 3-kinase (PI3k)/ Akt signaling in hepatocyte growth factor (HGF)-mediated lamellipodia formation, reactive oxygen species (ROS) generation, and motility of lung endothelial cells. J Biol Chem 2014; 289: 13476-13491. https://doi.org/10.1074/jbc.M113.527556

[52] LI Y, HUANG X, ZHONG W, ZHANG J, MA K. Ganglioside GM3 promotes HGF-stimulated motility of murine hepatoma cell through enhanced phosphorylation of cmet at specific tyrosine sites and PI3K/Akt-mediated migration signaling. Mol Cell Biochem 2013; 382: 83-92. https://doi.org/10.1007/ $\underline{\text { s11010-013-1720-9 }}$

[53] SHI MD, LIAO YC, SHIH YW, TSAI LY. Nobiletin attenuates metastasis via both ERK and PI3D/Akt pathways in HGFtreated liver cancer HepG2 cells. Phytomedicine 2013; 20: 743-752. https://doi.org/10.1016/j.phymed.2013.02.004

[54] MENAKONGKA A, SUTHIPHONGCHAI T. Involvement of PI3K and ERK1/2 pathways in hepatocyte growth factor-induced cholangiocarcinoma cell invasion. World J Gastroenterol 2010; 16: 713-722. https://doi.org/10.3748/wig.v16.i6.713 